Pharmaceutical Nanotechnology

\title{
Development of noncytotoxic PLGA nanoparticles to improve the effect of a new inhibitor of p53-MDM2 interaction
}

\author{
Ana M. Paiva ${ }^{\mathrm{a}, \mathrm{b}}$, Rita A. Pinto ${ }^{\mathrm{c}}$, Maribel Teixeira ${ }^{\mathrm{a}, \mathrm{d}, *}$, Carlos M. Barbosa $^{\mathrm{a}, \mathrm{e}}$, \\ Raquel T. Lima ${ }^{\mathrm{a}, \mathrm{c}}$, M. Helena Vasconcelos ${ }^{\mathrm{a}, \mathrm{c}, \mathrm{f}}$, Emília Sousa $^{\mathrm{a}, \mathrm{b}, * *}$, Madalena Pinto $^{\mathrm{a}, \mathrm{b}}$ \\ a Centro de Química Medicinal - Universidade do Porto (CEQUIMED-UP), Departamento de Ciências Químicas, Faculdade de Farmácia, Universidade do \\ Porto, Rua Jorge Viterbo Ferreira $n^{\circ} 228,4050-313$ Porto, Portugal \\ b Laboratório de Química Orgânica e Farmacêutica, Departamento de Ciências Químicas, Faculdade de Farmácia, Universidade do Porto, Rua Jorge Viterbo \\ Ferreira $n^{\circ}$ 228, 4050-313 Porto, Portugal \\ ' Cancer Drug Resistance Group, IPATIMUP - Institute of Molecular Pathology and Immunology of the University of Porto, Rua Dr. Roberto Frias, S/N, \\ 4200-465 Porto, Portugal \\ d Centro de Investigação em Ciências da Saúde (CICS), Instituto Superior de Ciências da Saúde - Norte, CESPU, Rua Central de Gandra $1317,4585-116$ \\ Gandra PRD, Portugal \\ e Laboratório de Tecnologia Farmacêutica, Departamento de Ciências do Medicamento, Faculdade de Farmácia, Universidade do Porto, Portugal \\ ${ }^{\mathrm{f}}$ Laboratório de Microbiologia, Departmento de Ciências Biológicas, Faculdade de Farmácia, Universidade do Porto, Portugal
}

\section{A R T I C L E I N F O}

Article history:

Received 23 May 2013

Received in revised form 5 July 2013

Accepted 8 July 2013

Available online 12 July 2013

\section{Keywords:}

Antitumor

Poly(D,L-lactide-co-glycolide)

Polymeric nanoparticles

Xanthones

\begin{abstract}
A B S T R A C T
One possible approach to overcome solubility complications and enhance the biological activity of drugs is their incorporation into drug delivery systems. Within this scope, several nanosphere and nanocapsule formulations of a new inhibitor of p53-MDM2 interaction (xanthone 1) were developed and their physicochemical properties analyzed. Through the investigation of the effect of several empty nanoparticles on the growth of MCF-7 cells, it was possible to observe that four out of five formulations were cytotoxic and that some correlations between the toxic potential of these polymeric nanoparticles and their properties/composition could be extrapolated. One empty formulation of nanocapsules developed by emulsification/solvent evaporation and containing PLGA, PVA and Mygliol ${ }^{\circledR} 812$ was found to be noncytotoxic to this cell line. The corresponding compound 1-loaded nanocapsules showed an incorporation efficiency of $77 \%$ and revealed to be more potent than the free drug against cell growth inhibition, which may be related to the enhancement in its intracellular delivery. In an integrative study, the intracellular uptake of nanocapsules was confirmed using fluorescent 6-coumarin and well as compound $\mathbf{1}$ release from nanocapsules. Overall, it was possible to enhance the effect of the hit inhibitor of p53-MDM2 interaction through the development of suitable noncytotoxic polymeric nanoparticles.
\end{abstract}

(c) 2013 Elsevier B.V. All rights reserved.

\section{Introduction}

The pharmacological relevance of xanthone derivatives has led the scientific community to isolate or synthesize xanthonic compounds in the search for novel drug candidates (Azevedo et al., 2012; Pinto et al., 2005). In the past few years, a large number of naturally-occurring and synthetic prenylated xanthones has been

\footnotetext{
* Corresponding author at: CICS, Instituto Superior de Ciências da Saúde - Norte, CESPU, Rua Central de Gandra 1317, 4585-116 Gandra PRD, Portugal. Tel.: +351 220428689; fax: +351226093390.

** Corresponding author at: CEQUIMED-UP, Laboratório de Química Orgânica e Farmacêutica, Departamento de Ciências Químicas, Faculdade de Farmácia, Universidade do Porto, Rua Jorge Viterbo Ferreira n ${ }^{\circ} 228,4050-313$ Porto, Portugal. Tel.: +351 220428689; fax: +351226093390.

E-mail addresses: maribel.teixeira@iscsn.cespu.pt (M. Teixeira), esousa@ff.up.pt (E. Sousa).
}

reported, particularly some with antitumor activity (Azevedo et al., 2012; Pinto and Castanheiro, 2009). Pre-clinical studies of natural prenylated xanthones have already suggested the extremely low oral bioavailability for the most investigated prenylxanthone, $\alpha$ mangostin (Fig. 1) (Chitchumroonchokchai et al., 2013; Li et al., 2011). Recently, a dihydropyranoxanthone, synthetized by some of us, 3,4-dihydro-12-hydroxy-2,2-dimethyl-2H,6H-pyrano[3,2b]xanthen-6-one (1, Fig. 1), presented significant antiproliferative and apoptotic inducing effects (Paiva et al., 2012; Palmeira et al., 2010) in human tumor cell lines. Both $\alpha$-mangostin (Leão et al., 2013a) and compound 1 (Leão et al., 2013b) were shown to be promising inhibitors of p53-MDM2 interaction, with compound 1 showing the highest inhibitory activity in a yeast target-based assay, mimicking the activity of known p53 activators. In addition, compound 1 was shown to inhibit P-glycoprotein in leukemia cells and presented an apparently high permeability coefficient across the human colon cancer cell line (Caco-2) (Sousa et al., 2012). 
<smiles>COc1c(O)cc2oc3cc(O)c(CC=C(C)C)c(O)c3c(=O)c2c1CC=C(C)C</smiles>

$\alpha$-mangostin<smiles>CC1(C)CCc2cc3c(=O)c4ccccc4oc3c(O)c2O1</smiles>

1

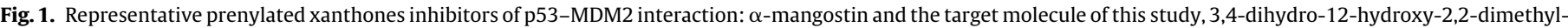
2H,6H-pyrano[3,2-b]xanthen-6-one (1).

As for the majority of promising new compounds, the success of compound 1 and other xanthone derivatives may be compromised by their poor solubility. In general, apart from the difficulty associated with the administration of water-insoluble drug substances, this property is often linked with poor bioavailability. One possible approach to overcome poor physiochemical properties and enhance the bioavailability of drugs is to associate the drug with a pharmaceutical carrier - a drug delivery system (DDS) which may enhance drug pharmacokinetics and cellular penetration (Chen et al., 2011).

Aliphatic poly(esters) like poly(lactide), poly(glycolide) and specially poly(D,L-lactide-co-glycolide) (PLGA) have been the most extensively investigated polymers for drug delivery, due to their excellent biocompatibility and biodegradability. Drugs entrapped in this type of polyester polymer matrix are released at a sustained rate, through diffusion of the drug in the polymer matrix and by degradation of the polymer matrix (Jong and Borm, 2008). Nanoparticles are submicron sized colloidal polymeric systems and according with the methods used for their preparation nanospheres or nanocapsules can be obtained. Nanospheres are matrix-type systems in which a drug is dispersed throughout the particles, whereas nanocapsules are vesicular systems in which a drug is confined to a cavity consisting of an inner liquid core surrounded by a polymeric membrane (Reis et al., 2006). This work is an integrated study that includes physicochemical characterization and biological analysis of compound 1-loaded polymeric nanoparticles which demonstrates uptake, and effect on the growth of a human breast adenocarcinoma cell line (MCF-7). In the present work, several polymeric nanosystems, nanocapsules and nanospheres, incorporating compound $\mathbf{1}$ were developed by different techniques: solvent displacement (SD), emulsification/solvent diffusion (ESD), and emulsification/solvent evaporation (ESE), and some formulation factors were studied in order to obtain nanoparticles with favorable technological characteristics. The cytotoxicity of both empty and loaded nanoparticle formulations was accessed in the MCF-7 (human breast adenocarcinoma) cell line, which was critical for the selection of the most suitable formulation. Furthermore, the intracellular uptake of nanocapsules containing a fluorescent probe (6-coumarin) was also investigated in the same cell line.

\section{Materials and methods}

\subsection{Materials}

3,4-Dihydro-12-hydroxy-2,2-dimethyl-2H,6Hpyrano[3,2$b$ ]xanthen-6-one (1) was obtained by a previously described method (Palmeira et al., 2010) and showed a purity of $98.5 \%$ by HPLC-DAD. PLGA 50:50 ( $\left.\mathrm{M}_{\mathrm{W}}: 50,000-75,000 \mathrm{Da}\right)$, Pluronic ${ }^{\circledR}$ F-68, glucose, polyvinyl alcohol (PVA), 6-coumarin, Tween ${ }^{\circledR} 80$ and $\operatorname{Span}^{\circledR} 80$ were purchased from Sigma-Aldrich Química
(Sintra, Portugal) and Mygliol ${ }^{\circledR} 812$ was purchased from Acofarma (Coimbra, Portugal). HPLC grade reagents methanol, acetonitrile and acetic acid were obtained from Carlo Erba Reagents, (Val de Reuil, Italy) and ultra-purified water was produced by a Millipore Milli-Q system (Simplicity ${ }^{\circledR}$ UV Ultrapure Water System, Millipore Corporation, Billerica, USA). All the other reagents and solvents were of analytical or HPLC grade.

\subsection{Apparatus and chromatographic conditions}

The HPLC analysis was performed in a Finnigan Surveyor Autosampler Plus and LC Pump Plus, Thermo Electron Corporation (Ohio, USA), equipped with a diode array detector TSP UV6000LP, and using a C-18 column ( $5 \mu \mathrm{m}, 250 \mathrm{~mm} \times 4.6 \mathrm{~mm}$ I.D.) from Macherey-Nagel (Düren, Germany). The injected volume was $20 \mu \mathrm{l}$ and the eluent was monitored at $254 \mathrm{~nm}$. Xcalibur ${ }^{\circledR} 2.0$ SUR 1 software, Thermo Electron Corporation (Ohio, USA) managed chromatographic data.

\subsection{Preparation of nanospheres}

Nanospheres containing compound $\mathbf{1}$ were prepared by SD with some modifications to the previously described methods (Fessi et al., 1989; Zili et al., 2005) (Table 1, formulations I-III). Briefly, an organic solution of $\mathbf{1}$, polymer, and containing or not a lipophilic surfactant was poured, under magnetic stirring into $10 \mathrm{ml}$ of aqueous solution of a hydrophilic surfactant (Pluronic ${ }^{\circledR} \mathrm{F}$ 68 or Tween ${ }^{\circledR} 80$ ). After 5 min of stirring, nanosphere dispersions were concentrated to $5 \mathrm{ml}$ under reduced pressure. Separation of non-incorporated compound was performed first by filtration (membrane with a porosity of $0.45 \mu \mathrm{m}$ ), and then by centrifugation at $1830 \mathrm{rpm}$ for $30 \mathrm{~min}$ (Sigma 1-14, Osterode am Harz, Germany) after solubilization of a certain amount of glucose for achieving a $5 \%$ $(\mathrm{w} / \mathrm{v})$ concentration, in order to avoid aggregation of the particles during the centrifugation step. The supernatant was discarded and the pellet containing the nanospheres was redispersed in water to complete the initial volume $(5 \mathrm{ml})$.

The development of nanospheres containing compound 1 prepared by ESD was based on a previously described procedure (Quintanar-Guerrero et al., 1996) with some modifications (Table 1, formulations IV-V). Briefly, the organic phase containing the polymer and the surfactant was poured into $10 \mathrm{ml}$ of the aqueous phase, while mixing with an high speed homogenizer $(20,000 \mathrm{rpm}$ for 5 min, IKA-T18 basic, Ultra Turrax ${ }^{\circledR}$, Germany) or by sonication (130 W, 90 s, VibraCell model-75186, Sonics, USA), to form an oil in water nanoemulsion, followed by evaporation under reduced pressure until the final volume of $5 \mathrm{ml}$ was reached. A certain amount of glucose for achieving a $10 \%(\mathrm{w} / \mathrm{v})$ concentration was solubilized and the separation of non-incorporated compound was performed first by filtration (membrane with a porosity of $0.45 \mu \mathrm{M}$ ) and then 
Table 1

Experimental conditions for the preparation of nanoparticles. ${ }^{\mathrm{a}}$

\begin{tabular}{|c|c|c|c|c|}
\hline Nanosphere formulations & I and II & III & IV and $\mathrm{V}$ & VI \\
\hline \multirow[t]{2}{*}{ Preparation method } & SD (Zili et al., 2005) & SD (Zili et al., 2005) & $\begin{array}{l}\text { ESD (Quintanar-Guerrero et al., } \\
\text { 1998) }\end{array}$ & $\begin{array}{l}\text { ESE (Panyam and Labhasetwar, } \\
\text { 2004) }\end{array}$ \\
\hline & \multicolumn{4}{|c|}{ Acetonic solution of $\mathbf{1}(1 \mathrm{mg} / \mathrm{ml})(0.75 \mathrm{ml})$} \\
\hline \multirow[t]{4}{*}{ Organic phase } & PLGA (50 mg) & PLGA (50 mg) & PLGA (70 mg) & PLGA (50 mg) \\
\hline & $\mathrm{CH}_{2} \mathrm{Cl}_{2}$ or $\mathrm{CH}_{3} \mathrm{OH}(0.5 \mathrm{ml})$ & $\mathrm{CH}_{3} \mathrm{OH}(0.5 \mathrm{ml})$ & Pluronic ${ }^{\circledR}$ F-68 (23.34 mg) & $\mathrm{CH}_{2} \mathrm{Cl}_{2}(1 \mathrm{ml})$ \\
\hline & \multirow[t]{2}{*}{ Acetone (q.s. $10 \mathrm{ml}$ ) } & $\operatorname{Span}^{\circledR} 80(16.65 \mathrm{mg})$ & \multirow[t]{2}{*}{ EtOAc $(3.5 \mathrm{ml})$} & \\
\hline & & Acetone (q.s. $10 \mathrm{ml}$ ) & & \\
\hline Aqueous phase & $\begin{array}{l}\text { Pluronic }{ }^{\circledR} \text { F-68 aqueous } \\
\text { solution }(0.25 \%, \mathrm{w} / \mathrm{v})(10 \mathrm{ml})\end{array}$ & $\begin{array}{l}\text { Tween }^{\circledR} 80 \text { aqueous solution } \\
(0.167 \%, \mathrm{w} / \mathrm{v})(10 \mathrm{ml})\end{array}$ & Water $(10 \mathrm{ml})$ & $\begin{array}{l}\text { PVA aqueous solution }(2.5 \% \text {, } \\
\mathrm{w} / \mathrm{v})(6 \mathrm{ml})\end{array}$ \\
\hline Stirring conditions & Magnetic stirring & & $\begin{array}{l}\text { High speed homogenization } \\
(20,000 \mathrm{rpm}, 5 \mathrm{~min}) \text { or } \\
\text { sonication }(130 \mathrm{~W}, 90 \mathrm{~s})\end{array}$ & Sonication $(130 \mathrm{~W}, 90 \mathrm{~s})$ \\
\hline Nanocapsule formulations & VII & VIII & IX & $\mathrm{X}$ \\
\hline \multirow[t]{2}{*}{ Preparation method } & SD (Bernardi et al., 2009) & SD (Zili et al., 2005) & ESD & $\begin{array}{l}\text { ESE (Panyam and Labhasetwar, } \\
\text { 2004) }\end{array}$ \\
\hline & \multicolumn{3}{|l|}{ Compound $\mathbf{1}$ solution in } & \\
\hline \multirow[t]{4}{*}{ Organic phase } & Mygliol $^{\circledR} 812(3.5 \mathrm{mg} / \mathrm{ml})$ & Mygliol $^{\circledR} 812(3.5 \mathrm{mg} / \mathrm{ml})$ & Mygliol $^{\circledR} 812(3.5 \mathrm{mg} / \mathrm{ml})$ & Mygliol $^{\circledR} 812(3.5 \mathrm{mg} / \mathrm{ml})$ \\
\hline & $(0.55 \mathrm{ml})$ & $\begin{array}{l}(0.50 \mathrm{ml}) \\
\text { PLGA ( } 50 \mathrm{mg})\end{array}$ & $(0.45 \mathrm{ml})$ & $(0.40 \mathrm{ml})$ \\
\hline & \multirow{2}{*}{ Acetone $(8.75 \mathrm{ml})$} & $\begin{array}{l}\text { PLGA (50 mg) } \\
\operatorname{Span}^{\circledR} 80(100 \mathrm{mg})\end{array}$ & $\begin{array}{l}\text { PLGA ( } 144 \mathrm{mg} \text { ) } \\
\text { Pluronic }{ }^{\circledR} \text { F-68 (60.12 mg) }\end{array}$ & $\begin{array}{l}\mathrm{PLGA}(50 \mathrm{mg}) \\
\mathrm{CH}_{3} \mathrm{OH}(0.4 \mathrm{ml})\end{array}$ \\
\hline & & Acetone $(8.75 \mathrm{ml})$ & EtOAc $(9 \mathrm{ml})$ & $\mathrm{CH}_{2} \mathrm{Cl}_{2}(1 \mathrm{ml})$ \\
\hline Aqueous phase & $\begin{array}{l}\text { Pluronic }^{\circledR} \text { F-68 aqueous } \\
\text { solution }(0.385 \%, w / v)(10 \mathrm{ml})\end{array}$ & $\begin{array}{l}\text { Tween }^{\circledR} 80 \text { aqueous solution } \\
(1 \%, \mathrm{w} / \mathrm{v})(10 \mathrm{ml})\end{array}$ & Water $(20 \mathrm{ml})$ & $\begin{array}{l}\text { PVA aqueous solution (2.5\%, } \\
\mathrm{w} / \mathrm{v})(6 \mathrm{ml})\end{array}$ \\
\hline Stirring conditions & Magnetic stirring & Magnetic stirring & Sonication (130 W, $90 \mathrm{~s})$ & \\
\hline
\end{tabular}

a For each formulation $\mathrm{I}-\mathrm{X}$, corresponding empty formulations (i-X) were also prepared.

by centrifugation for $1 \mathrm{~h}$ at $4578 \mathrm{rpm}$ (HettichMikro 200, Buckinghamshire, England). The supernatant was discarded and the pellet containing the nanospheres was redispersed in water to complete the initial volume $(5 \mathrm{ml})$.

An additional formulation was developed by ESE (Panyam and Labhasetwar, 2004 and references therein), as described in Table 1 (formulation VI). In brief, the organic phase containing compound 1 and the polymer was poured into $6 \mathrm{ml}$ of an aqueous solution of PVA, and mixed by sonication ( $130 \mathrm{~W}, 90 \mathrm{~s})$ to form an oil in water nanoemulsion. This nanoemulsion was stirred at room temperature for $4 \mathrm{~h}$ to evaporate organic solvent, until the final volume of $5 \mathrm{ml}$ was reached. Nanoparticles were recovered by ultracentrifugation ( $1 \mathrm{~h}$ at $4578 \mathrm{rpm}$, Hettich Mikro 200, Buckinghamshire, England) and washed with Milli Q water to remove unentrapped compound and PVA.

Empty nanospheres (formulations i-vi) were prepared according to the described procedures but omitting compound $\mathbf{1}$ in the organic phase.

\subsection{Preparation of nanocapsules}

Nanocapsules containing compound 1 were prepared by the SD previously described method (Bernardi et al., 2009; Zili et al., 2005), as described in Table 1 (formulations VII-VIII). Concisely, an acetonic solution of PLGA containing or not the lipophilic surfactant $\operatorname{Span}^{\circledR} 80$ was prepared. Compound 1 was dissolved in Mygliol ${ }^{\circledR}$ $812(3.5 \mathrm{mg} / \mathrm{ml})$ and 0.50 or $0.55 \mathrm{ml}$ of this solution was added to the previous prepared acetonic solution. The final organic phase was poured into an aqueous solution of a surfactant (Pluronic ${ }^{\circledR} \mathrm{F}$ 68 or Tween ${ }^{\circledR} 80$ ) under moderate stirring for 5 min. Nanocapsules dispersion final volume $(5 \mathrm{ml})$ was reached by evaporation under reduced pressure. The non-encapsulated compound 1 was separated by ultrafiltration (centrifugal filter devices Centricon K10, Amicon, Millipore) at $4000 \mathrm{rpm}$ for $30 \mathrm{~min}$ (Beckman UL-80 ultracentrifuge, Albertville, USA), and the volume completed with Milli Q water.

Compound 1-loaded nanocapsules were also prepared by ESD by modification of a described procedure (Quintanar-Guerrero et al., 1998) (Table 1, formulation IX). Briefly, compound 1 was dissolved in Mygliol ${ }^{\circledR} 812(3.5 \mathrm{mg} / \mathrm{ml})$ and $0.45 \mathrm{ml}$ of this oily solution was added to a solution of PLGA and Pluronic ${ }^{\circledR}$ F68 in ethyl acetate. The final organic solution was poured into $20 \mathrm{ml}$ of MilliQ water and submitted to sonication ( $130 \mathrm{~W}, 90 \mathrm{~s})$. The nanocapsules dispersion was concentrated under reduced pressure to reach the final volume of $5 \mathrm{ml}$. The amount of non-encapsulated compound 1 was separated by ultrafiltration using centrifugal filter devices (Centricon K10, Amicon, Millipore) at $4000 \mathrm{rpm}$ for $30 \mathrm{~min}$ (Beckman UL-80 ultracentrifuge, Albertville, USA).

Finally, a different formulation was developed by ESE, based on a described procedure (Panyam and Labhasetwar, 2004) (Table 1, formulation X). In brief, a solution of PLGA in dichloromethane was prepared and sonicated with methanol and a solution of compound 1 in Mygliol $^{\circledR} 812(3.5 \mathrm{mg} / \mathrm{ml})$. This organic solution was poured into $6 \mathrm{ml}$ of an aqueous solution of PVA and sonicated $(130 \mathrm{~W}, 90 \mathrm{~s})$. The final volume of nanocapsules dispersion $(5 \mathrm{ml})$ was obtained by stirring for $4 \mathrm{~h}$, at room temperature. The amount of non-encapsulated compound $\mathbf{1}$ and residual PVA was separated by ultrafiltration using centrifugal filter devices at $4000 \mathrm{rpm}$ for 30 min (Beckman UL-80 ultracentrifuge, Albertville, USA).

Empty nanocapsules (vii-x) were prepared according to the same procedures, using the same amount of oil, but without compound 1 .

\subsection{Physicochemical characterization}

\subsubsection{Particle size and zeta potential}

Particle size analysis of nanoparticles was performed by dynamic light scattering (DLS). Zeta potential was evaluated by laser Doppler anemometry (LDA). In both determinations, samples were analyzed following appropriate dilution with ultrapure water, using a Brookhaven, BI-MAS90Plus (Brokhaven Instruments, New York, USA). For nanospheres, the dilution used was $1: 2$ (nanospheres:water), and for nanocapsules $1: 100$ and $1: 200$ (nanocapsules:water). Values presented are the mean \pm standard deviation (SD) of at least three different batches of each nanoparticle formulation. 


\subsubsection{Quantification of compound 1 content in nanoparticles}

Quantification of the nanoparticles of compound 1 was performed by a HPLC validated method (unpublished work). Sample solutions were prepared by dissolving an aliquot of the dihydropyranoxanthone 1 nanosphere or nanocapsule dispersions in acetonitrile (corresponding to a dilution of $1 / 50$ and $1 / 500$, respectively) and subjected to HPLC analysis. Considering an entrapment of compound 1 into nanoparticles of $100 \%$, the obtained sample solutions had a maximum theoretical concentration of $3 \mathrm{mg} / \mathrm{ml}$ in nanospheres and ranging from 0.56 to $0.77 \mathrm{mg} / \mathrm{ml}$ in nanocapsules, depending on the procedure used. All analyses were performed in triplicate and the results presented are the mean \pm SD. Incorporation efficiency (IE) was calculated as follows:

$\mathrm{IE}(\%)=\frac{A}{B} \times 100$

where $A$ is the compound $\mathbf{1}$ concentration $(\mu \mathrm{g} / \mathrm{ml})$ in the nanoparticle dispersions and $B$ is the theoretical compound $\mathbf{1}$ concentration $(\mu \mathrm{g} / \mathrm{ml})$.

\subsection{Scanning electron microscopy (SEM)}

Scanning electron microscopy (SEM) was performed to evaluate the surface morphology of nanoparticles using a SEM equipment (JEOL JSM 6301F), at CEMUP (Centro de Materiais da Universidade do Porto). Nanoparticles samples were dried for $24 \mathrm{~h}$ before the analysis. A small amount of the dried nanoparticles was applied directly on a metallic surface stand without coating.

\subsection{Effect on the growth of MCF-7 human tumor cell line}

Cells $\left(5.0 \times 10^{3}\right.$ cells/well $)$ were plated in 96 -well plates and allowed to adhere for $24 \mathrm{~h}$. Cells were then treated with serial dilutions of compound 1 alone (from $18.75 \mu \mathrm{M}$ to $150.00 \mu \mathrm{M}$ ), compound 1-incorporated into nanocapsules (from 0.62 to $50.00 \mu \mathrm{M}$ ) or empty nanocapsules (using equal volumes to the ones used for the compound 1-incorporated into nanocapsules). Following $48 \mathrm{~h}$ incubation, the effect of these treatments in cell growth was analyzed with the sulforhodamine B (SRB) assay according to the procedure adopted by the National Cancer Institute (NCI, USA) (Queiroz et al., 2010; Vaz et al., 2010; Vichai and Kirtikara, 2006). Briefly, after washing with PBS, cells were fixed in situ with $10 \%$ trichloroacetic acid, stained with SRB and washed with $1 \%$ acetic acid. The bound dye was then solubilized with $10 \mathrm{mM}$ Tris Base and absorbance was measured at $510 \mathrm{~nm}$ in a microplate reader (Biotek Instruments Inc. Synergy XS, Winooski, USA). A DMSO control (the vehicle of compound $\mathbf{1}$ ) was also included in the experiments.

\subsection{Internalization studies}

MCF-7 cells $\left(3.5 \times 10^{5}\right.$ cells/well) were seeded on glass coverslips (in 24 well plates) and allowed to adhere for $24 \mathrm{~h}$. Cells were then exposed to nanocapsules incorporating $10 \mu \mathrm{M}$ of 6 -coumarin (fluorescent compound) or to empty nanocapsules (equal volume to the used for the nanocapsules incorporating coumarin). The internalization of the nanocapsules was analyzed at different timepoints up to $48 \mathrm{~h}$. This was possible by washing the cells with PBS, fixing with $4 \%$ paraformaldehyde (in PBS) and mounting the coverslips in Vectashield ${ }^{\circledR}$ with DAPI (4'-6-diamidino-2-phenylindole, Vector Laboratories). Cells were observed with a fluorescence microscope (Leica DMIRE2000).

\subsection{In vitro release studies}

In vitro release studies of compound $\mathbf{1}$, for the most promising nanocapsule formulation developed (formulation $\mathrm{X}$ ) - that showed the lowest cytotoxic effect against MCF-7 cells -, were carried out at $37^{\circ} \mathrm{C}$, by the bulk equilibrium reverse dialysis bag technique (Levy and Benita, 1990). A volume of nanocapsule dispersion corresponding to $10 \%$ of the maximum theoretical aqueous solubility of compound $1(1.6 \mu \mathrm{g} / \mathrm{ml})$, in phosphate buffer saline $0.1 \mathrm{M}, \mathrm{pH} 7.4$ (PBS) at $37^{\circ} \mathrm{C}$, was placed directly into $200 \mathrm{ml}$ of PBS. To this solution, eight dialysis bags (cellulose membrane Mw cut-off 10,000 Da, Sigma-Aldrich, Sintra, Portugal) containing $1 \mathrm{ml}$ of PBS, were previously immersed, and submitted to mechanical stirring at $37^{\circ} \mathrm{C}$. At given time intervals, a dialysis bag was withdrawn from the release medium and the compound $\mathbf{1}$ content was directly assayed by HPLC. Calibration solutions over the range of $0.5-3.0 \mu \mathrm{g} / \mathrm{ml}$ were prepared by diluting compound 1 stock solution in acetonitrile with PBS. Values reported are the mean \pm SD obtained for three different batches of the referred formulations.

\subsection{Calculations and statistics}

IBM SPSS Statistics-19 ${ }^{\circledR}$ was applied for statistic calculations ( $t$ test and $f$ test).

\section{Results}

\subsection{Characterization of compound 1-loaded nanoparticles}

Six different formulations of nanospheres were prepared (I-VI, Table 1) and their particle size, polidispersity index (PI), and zeta potential determined (Table 2). Compound 1-loaded and empty nanosphere dispersions presented macroscopic homogeneous aspect, with a bluish opalescent appearance due to Tyndall effect.

Overall, the results showed lower sizes with $\mathrm{SD}(<150 \mathrm{~nm})$ when compared with ESD and ESE ( $<400 \mathrm{~nm}$ ) (Table 2$)$. When comparing the mean particle size values between loaded and empty formulations, only in formulation II (compound 1-loaded nanospheres prepared by SD, with methanol as co-solvent) no significantly differences $(P>0.05)$ to empty nanospheres were observed. Regarding compound 1-loaded nanospheres, the use of methanol or dichloromethane, as co-solvents, had no influence in the mean particle size obtained $(P>0.05)$. Using Span ${ }^{\circledR} 80 /$ Tween $^{\circledR} 80$ (formulation III) instead of Pluronic ${ }^{\circledR}$ F-68 (formulations I and II) led to nanosphere dispersions with lower values of mean particle size ( $\sim 96 \mathrm{~nm}, P<0.05)$. Nanospheres prepared using SD and ESD technique (formulations $I-V$ ) exhibited negative surface charge with zeta potential values lower than $-28 \mathrm{mV}$. The highest values of mean particle size were found for the nanospheres prepared with the ESE technique (formulation VI); zeta potential values were also the lowest, what could foreshadow low stability for this formulations since more pronounced zeta potential values (being positive or negative) tend to stabilize particle suspension. In this formulation, the presence of PVA enhanced a faster resuspension after the washing step.

The incorporation efficiency values of compound 1 into PLGA nanospheres (formulations I-VI) were also investigated (Table 3 ). In the SD method, the use of methanol or dichloromethane as cosolvents, did not significantly affect the incorporation efficiency $(P>0.05)$ (formulations I and II). The overall results revealed the ESE as the most suitable method for the preparation of nanospheres containing compound $\mathbf{1}$ (formulation $\mathrm{VI}$ ), presenting the highest incorporation efficiency values, although, the incorporation efficiency achieved was lower than $40 \%$.

The four different nanocapsules formulations developed (formulations VII-X) were also investigated for their particle size, PI, and zeta potential (Table 2). The maximum amount of oil core (Mygliol ${ }^{\circledR} 812$ ) that allows the preparation of stable 
Table 2

Physicochemical properties of the obtained nanoparticles.

\begin{tabular}{|c|c|c|c|c|}
\hline Method & Formulation & Diameter (nm) & PI & Zeta potential (mV) \\
\hline \multicolumn{5}{|c|}{ Nanospheres } \\
\hline \multirow{6}{*}{ SD } & I & $171.48 \pm 8.57$ & $0.20 \pm 0.06$ & $-33.33 \pm 0.27$ \\
\hline & $\mathrm{i}$ & $131.80 \pm 3.70$ & $0.14 \pm 0.03$ & $-32.07 \pm 0.75$ \\
\hline & II & $149.22 \pm 13.49$ & $0.08 \pm 0.02$ & $-33.72 \pm 1.38$ \\
\hline & ii & $109.53 \pm 1.45$ & $0.13 \pm 0.01$ & $-35.97 \pm 0.42$ \\
\hline & III & $95.67 \pm 2.32$ & $0.20 \pm 0.02$ & $-42.72 \pm 0.83$ \\
\hline & iii & $139.80 \pm 3.95$ & $0.13 \pm 0.01$ & $-33.63 \pm 2.53$ \\
\hline \multirow{4}{*}{ ESD } & IV & $194.48 \pm 25.67$ & $0.14 \pm 0.02$ & $-33.99 \pm 2.71$ \\
\hline & iv & $361.68 \pm 33.16$ & $0.37 \pm 0.02$ & $-27.58 \pm 0.27$ \\
\hline & $\mathrm{V}$ & $166.67 \pm 7.48$ & $0.15 \pm 0.02$ & $-41.41 \pm 1.87$ \\
\hline & $\mathrm{v}$ & $158.23 \pm 0.83$ & $0.10 \pm 0.01$ & $-38.50 \pm 3.65$ \\
\hline \multirow[b]{2}{*}{ ESE } & VI & $400.53 \pm 8.83$ & $0.19 \pm 0.02$ & $-33.23 \pm 3.33$ \\
\hline & vi & $238.53 \pm 12.91$ & $0.076 \pm 0.01$ & $-9.18 \pm 1.95$ \\
\hline \multicolumn{5}{|c|}{ Nanocapsules } \\
\hline \multirow{4}{*}{ SD } & VII & $219.3 \pm 3.3$ & $0.15 \pm 0.04$ & $-24.57 \pm 4.3$ \\
\hline & vii & $213.3 \pm 4.3$ & $0.16 \pm 0.05$ & $-35.51 \pm 3.1$ \\
\hline & VIII & $319.07 \pm 21.8$ & $0.20 \pm 0.01$ & $-39.34 \pm 1.0$ \\
\hline & viii & $368.72 \pm 39.2$ & $0.26 \pm 0.01$ & $-35.22 \pm 3.4$ \\
\hline \multirow[b]{2}{*}{ ESD } & IX & $210.27 \pm 0.7$ & $0.09 \pm 0.002$ & $-38.07 \pm 1.2$ \\
\hline & ix & $241.47 \pm 2.8$ & $0.06 \pm 0.01$ & $-40.50 \pm 1.2$ \\
\hline \multirow[b]{2}{*}{ ESE } & $\mathrm{X}$ & $283.93 \pm 12.18$ & $0.093 \pm 0.006$ & $-15.20 \pm 0.64$ \\
\hline & $\mathrm{x}$ & $238.53 \pm 0.09$ & $0.097 \pm 0.025$ & $-14.37 \pm 0.49$ \\
\hline
\end{tabular}

nanocapsule dispersions was determined for every preparation technique employed. For nanocapsules prepared by SD, formulations containing $0.40,0.50$ and $0.55 \mathrm{ml}$ of Mygliol ${ }^{\circledR} 812$ showed a small pellet at the bottom of the flask (attributed to nanospheres) and a cream layer at the surface corresponding to nanocapsules; no free oil could be detected in these formulations indicating that the oil was completely coated by the polymer. The formulations including $0.60 \mathrm{ml}$ of Mygliol ${ }^{\circledR} 812$ showed a free oil layer at the surface of the dispersions upon centrifugation indicating poor stability. Therefore the amount of oil selected to be used, which allowed the preparation of stable nanocapsule formulations was $0.55 \mathrm{ml}$. Then, for nanocapsule preparation $0.55 \mathrm{ml}$ of compound 1 solution in Mygliol ${ }^{\circledR} 812$ was used. Nanocapsules formulations presented macroscopic homogeneous aspects, with an opalescent milky-like appearance. For all formulations mean particle size ranged from $\sim 210$ to $370 \mathrm{~nm}$. The mean particle size of the formulations developed was not affected by the incorporation of compound $1(P>0.05)$. When using Pluronic ${ }^{\circledR}$ F-68 as surfactant (formulation VII and IX) instead of Tween ${ }^{\circledR} 80 / \operatorname{Span}^{\circledR} 80$ (formulation VIII), nanocapsules dispersions showed lower particle size values $(P<0.05)$. Zeta potential values showed that, for both empty and compound 1-loaded nanocapsules, negative surface charges were achieved, ranging from $-14.37 \pm 0.49$ to $-40.50 \pm 1.2 \mathrm{mV}$, which indicates that stable formulations were produced with this method.

Incorporation efficiency values of compound 1 in PLGA nanocapsules were also determined (Table 3 ). With the SD technique, using Tween- $80^{\circledR} /$ Span- $80^{\circledR}$ (formulation VIII) instead of Pluronic F-68 ${ }^{\circledR}$ (formulation VII) as surfactants, the final concentration and incorporation efficiency values, raised from $196.18 \pm 24.16$ to $323.57 \pm 2.67 \mu \mathrm{g} / \mathrm{ml}$, respectively ( $\sim 30 \%$ increased). Overall, the incorporation efficiency for nanocapsules was better than the one achieved for nanospheres (Table 3) with formulation VIII presenting an incorporation efficiency of compound 1 of $84 \%$. Moreover, the developed nanocapsule dispersions showed higher concentrations than the respective theoretical aqueous solution of compound $\mathbf{1}(16 \mu \mathrm{g} / \mathrm{ml}, \mathrm{ACD} /$ Labs program $)$ : 20 fold for formulation VIII, 15 fold for IX and 13 fold for X, respectively.

\subsection{Effect on the growth of MCF-7 human tumor cell line}

Based on the technological parameters, five of the developed formulations were selected for further evaluation in the human breast adenocarcinoma cell line MCF-7, regarding the cell growth inhibitory effect. The chosen formulations were: nanospheres developed by SD and ESE (formulations III and VI) and nanocapsules developed by SD, ESD, and ESE (formulations VIII, IX, and formulation X). By analysing the effect of the different empty nanoparticles on the MCF-7 cell growth (with the SRB assay), it was possible to observe that only the empty formulation of nanocapsules developed by ESE (formulation $\mathrm{x}$ ), did not present major cytotoxicity to this cell line at the concentrations analyzed (Fig. 2). The other

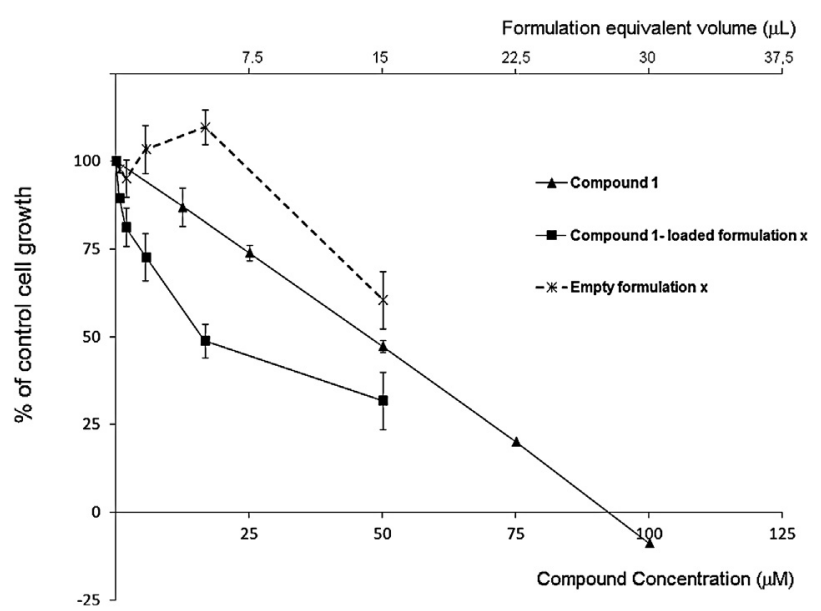

Fig. 2. Effect of empty and compound 1-loaded formulation $\mathrm{X}$ in the cell growth of MCF-7 cells. Cells were treated for $48 \mathrm{~h}$ with increasing concentration of compound $\mathbf{1}$, compound $\mathbf{1}$ incorporated into nanocapsules (compound $\mathbf{1}$ loaded formulation $\mathrm{X}$ ) or with equal volumes of empty nanocapsules (empty formulation $\mathrm{x}$ ) and analyzed with the SRB assay. Results are represented as \% of cell growth, considering the values for untreated cells as $100 \%$. Results are the mean \pm standard error of five independent experiments. 
Table 3

Incorporation efficiency of compound $\mathbf{1}$ in nanoparticles.

\begin{tabular}{|c|c|c|c|c|}
\hline Method & Formulation & $\begin{array}{l}\text { Compound } 1 \text { theoretical } \\
\text { concentration }(\mu \mathrm{g} / \mathrm{ml})\end{array}$ & $\begin{array}{l}\text { Compound } 1 \text { final } \\
\text { concentration }(\mu \mathrm{g} / \mathrm{ml})\end{array}$ & $\begin{array}{l}\text { Incorporation } \\
\text { efficiency (\%) }\end{array}$ \\
\hline \multicolumn{5}{|c|}{ Nanospheres } \\
\hline \multirow{4}{*}{ SD } & I & \multirow{6}{*}{150} & $37.77 \pm 6.07$ & $25.18 \pm 1.85$ \\
\hline & II & & $39.12 \pm 4.69$ & $26.08 \pm 3.12$ \\
\hline & III & & $43.04 \pm 1.08$ & $28.69 \pm 0.72$ \\
\hline & IV & & $28.23 \pm 0.78$ & $18.82 \pm 0.39$ \\
\hline ESD & $\mathrm{V}$ & & $33.98 \pm 3.66$ & $22.65 \pm 2.44$ \\
\hline ESE & VI & & $58.17 \pm 7.13$ & $38.78 \pm 4.75$ \\
\hline \multicolumn{5}{|c|}{ Nanocapsules } \\
\hline & VII & 385 & $196.18 \pm 24.16$ & $56.05 \pm 6.90$ \\
\hline SD & VIII & 350 & $323.57 \pm 2.67$ & $84.04 \pm 0.69$ \\
\hline ESD & IX & 315 & $242.97 \pm 2.85$ & $77.99 \pm 0.90$ \\
\hline ESE & $\mathrm{X}$ & 280 & $209.56 \pm 32.35$ & $77.85 \pm 11.55$ \\
\hline
\end{tabular}

investigated empty formulations presented cytotoxicity (data not shown), which may be explained by the amount of excipients used in their development (Table 4).

When comparing the cell growth inhibitory effect (in MCF-7 cells) of the free compound 1 with the effect of formulation $\mathrm{X}$, the $\mathrm{GI}_{50}$ values (concentration that inhibits cell growth by $50 \%$ ) significantly decreased from $46.8 \pm 1.8 \mu \mathrm{M}$ to $16.3 \pm 2.1 \mu \mathrm{M}(P<0.05)$ (Fig. 2). Moreover, no apparent cellular toxicity was observed following treatment with the empty nanocapsules, at the volume corresponding to the determined $\mathrm{GI}_{50}$ (Fig. 2).

\subsection{Internalization studies}

A green fluorescent compound (6-coumarin) was incorporated into formulation $\mathrm{x}$ and following treatment with nanocapsules incorporating 6-coumarin, cells were observed at different timepoints. Green fluorescence (indicating the presence of coumarin) was evident in the cell cytosol immediately after the nanocapsules incorporating 6-coumarin were added to the cells (Fig. 3).

Although the initial green fluorescence was weak, it became stronger and diffused throughout the cell cytoplasm at the other time-points analyzed. The intracellular concentration was particularly strong $6 \mathrm{~h}$ following treatment and the intensity reduced at $48 \mathrm{~h}$ following treatment, indicating that the coumarin was probably metabolized or eliminated by the cells.

\subsection{Scanning electron microscopy (SEM)}

SEM was used to investigate the morphology of formulation $\mathrm{X}$ (Fig. 4A). Nanocapsules displayed a spherical shape with a smooth surface and no aggregation was observed. No difference was observed in the morphological properties of nanocapsules due to presence of the drug. In fact, SEM analysis confirmed the nanometric size of formulation X determined by DLS (Fig. 4A).

\subsection{In vitro release}

In vitro release studies of compound 1-loaded nanocapsules formulation were performed under "sink conditions" (Levy and Benita, 1990), to avoid the interference of compound 1 solubility in these experiments (Fig. 4B). As observed in Fig. 4B, an important release of compound 1 from nanocapsules (formulation $\mathrm{X}$ ) during the first $2 \mathrm{~h}$ ( $>80 \%$ release) followed by a slow release up to the end of the assay $(24 \mathrm{~h})$ was observed. The kinetic process is probably governed by the oil-water partition coefficient as described for other nanocapsule formulations (Teixeira et al., 2005a).

\section{Discussion}

This study aimed to develop suitable polymeric nanoparticles incorporating the xanthone $\mathbf{1}$, an inhibitor of p53-MDM2 interaction. This approach was previously demonstrated to be efficient in improving the NO production inhibitory effect of simple oxygenated xanthones (Teixeira et al., 2005b). To achieve a suitable formulation, several techniques and excipients were used in the preparation of polymeric nanoparticles and investigated for their cytotoxicity in a human breast adenocarcinoma cell line (MCF-7).

Six different formulations of nanospheres and four different formulations of nanocapsules were developed and their technological parameters analyzed. The overall results indicates that the different techniques employed were appropriate in achieving stable polymeric formulations showing zeta potential values near $-30 \mathrm{mV}$, revealing to be stable in suspension, as the surface charge prevents aggregation of the particles (Mohanraj and Chen, 2006).

It is always a challenge to formulate nanoparticles with the smallest size possible but with maximum stability. Smaller particles have larger surface area, which means that most of the compound associated would be at or near the particle surface, leading to a fast drug release, also having greater risk of aggregation during storage and transportation (Mohanraj and Chen, 2006); whereas, larger particles have large cores which allow more

Table 4

Amount of excipients delivered to the cells. ${ }^{a}$

\begin{tabular}{|c|c|c|c|c|c|c|c|}
\hline Formulations & [Compound 1 nanoparticles] ${ }^{\mathrm{b}}(\mu \mathrm{M})$ & $\begin{array}{l}\text { Dilution } \\
\text { factor }\end{array}$ & $\begin{array}{l}\text { PLGA } \\
(\mathrm{mg} / \mathrm{ml})\end{array}$ & $\begin{array}{l}\text { PVA } \\
(\mathrm{mg} / \mathrm{ml})\end{array}$ & $\begin{array}{l}\text { Tween }^{\circledR} 80 / \text { Span }^{\circledR} \\
80(\mathrm{mg} / \mathrm{ml})\end{array}$ & $\begin{array}{l}\text { Pluronic }^{\circledR} \\
(\mathrm{mg} / \mathrm{ml})\end{array}$ & Mygliol $^{\circledR} 812(\mathrm{ml} / \mathrm{ml})$ \\
\hline III & 134 & N.A. & 10.00 & - & 20.00 & - & - \\
\hline VI & 291 & 1.94 & 5.15 & 15.46 & - & - & - \\
\hline VIII & 1108 & 7.40 & 1.35 & - & 10.31 & - & 13.51 \\
\hline IX & 703 & 4.70 & 2.98 & - & - & 0.99 & 19.15 \\
\hline $\mathrm{X}$ & 697 & 4.60 & 2.17 & 6.52 & - & - & 17.39 \\
\hline
\end{tabular}

a For each formulation, corresponding empty formulations were also investigated.

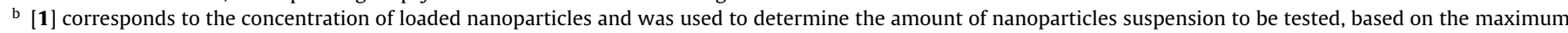
concentration of compound 1 tested $(150 \mu \mathrm{M})$.

N.A. Not applied ([Compound 1] in nanoparticles below the maximum concentration used). 

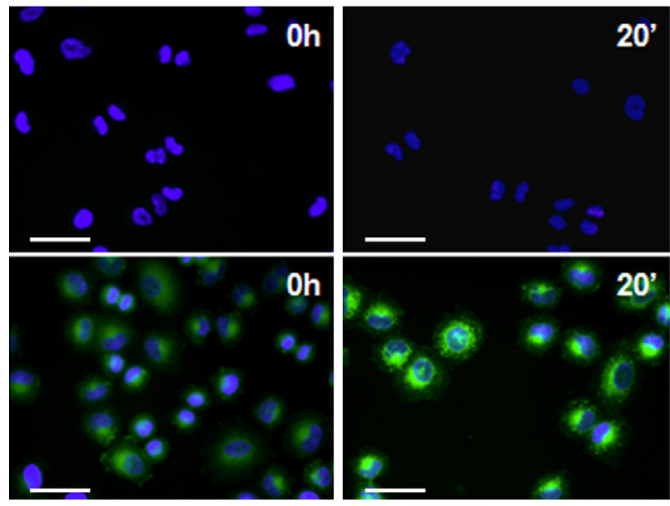

DAPI

Coumarin
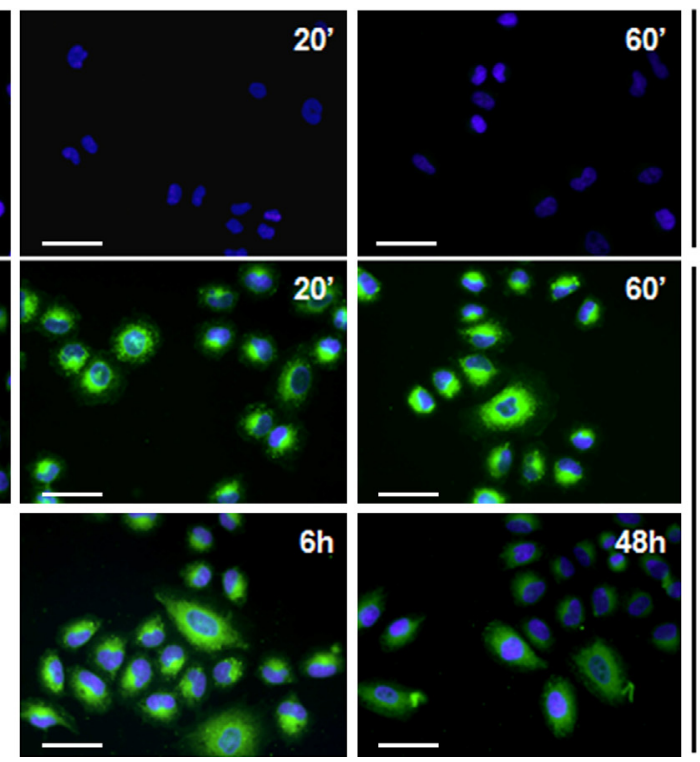

\section{Empty \\ formulation $\mathrm{x}$}

\section{6-coumarin loaded formulation $x$}

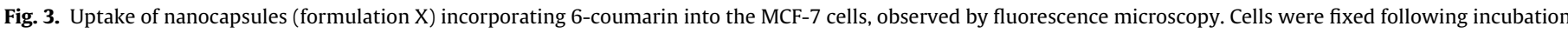

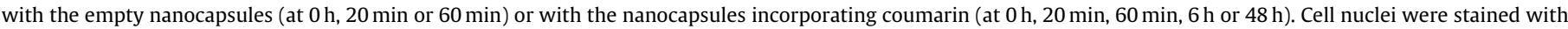
DAPI and the cytoplasmic green fluorescence resulted from coumarin.

compound to be encapsulated and slowly diffuse out. In general, the nanospheres obtained furnished formulations with smaller particle size but lower incorporation efficiency, when comparing with nanocapsules. These results were predictable, since the dihydropyranoxanthone $\mathbf{1}$ is lipophilic and could therefore be better dissolved in the oil core of the nanocapsules.

The incorporation of compound $\mathbf{1}$ into nanosystems aims mainly at overcoming problems related to the compound with low water solubility. For all the conditions studied, the final concentration of compound 1-loaded nanoparticles was higher than the calculated aqueous solubility concentration $(16 \mu \mathrm{g} / \mathrm{ml})$. Based on these data, two formulations of nanospheres (III and VI) and three formulations of nanocapsules (VIII-X), all with favorable physicochemical properties, were selected for further investigations.

In the present study, the cytotoxicity evaluation in $\mathrm{MCF}-7$ cell line of both empty and loaded formulations limited the future use of four out of five developed nanoparticles. Considering the effect of Tween ${ }^{\circledR} 80$ and $\operatorname{Span}^{\circledR} 80$, although they have been described as being nontoxic and being allowed for intravenous administration
(Rowe et al., 2009), the amounts used for the preparation of above described nanoparticles were found to influence the cytotoxicity of formulations III and VIII (Table 4) which could be related to their cell permeabilization effects (Olivier, 2005); similar conclusions could be drawn for Pluronic ${ }^{\circledR}$ (formulation IX, Table 4). In contrast, the dispersing oil Mygliol ${ }^{\circledR}$ was also not responsible for the observed toxicity, since nanocapsules X used higher amounts of oil (when compared with nanocapsules VIII) without cytotoxicity at compound $\mathbf{1} \mathrm{GI}_{50}$ value, independently of their zeta potentials (Table 2). In what concerns PLGA, from the obtained results, one may hypothesize that the toxicity observed is not directly related to this excipient in accordance to previously described toxicological studies (Semete et al., 2010). Indeed, while for the nanocapsules VIII, the amount of PLGA was $1.35 \mathrm{mg} / \mathrm{ml}$, and this formulation was toxic, for nanocapsules $\mathrm{X}$, the amount used was higher $(2.17 \mathrm{mg} / \mathrm{ml})$ and no cytotoxicity was observed at compound $\mathbf{1} \mathrm{GI}_{50}$ values. PVA is also known to have low toxicity (DeMerlis and Schoneker, 2003) but due to several variables in formulations VI and X no extrapolations can be drawn. Since the toxic potential of nanoparticles has

\section{A}

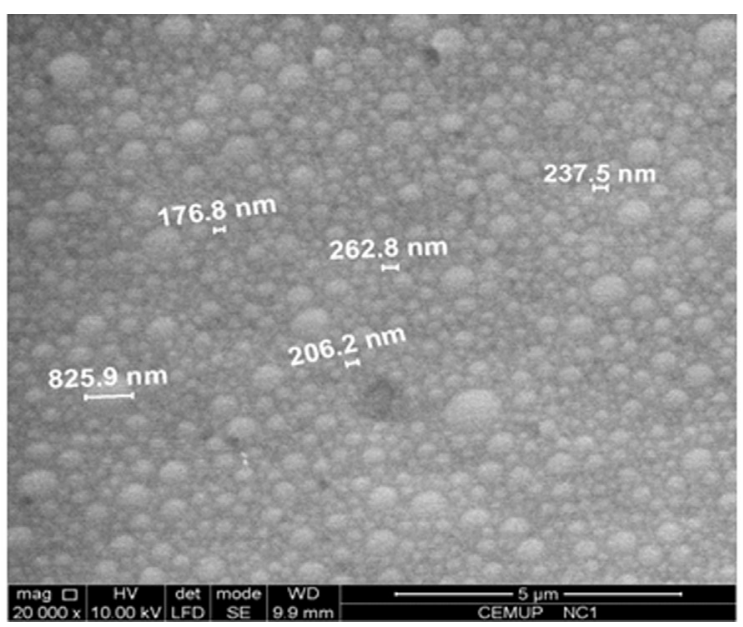

B

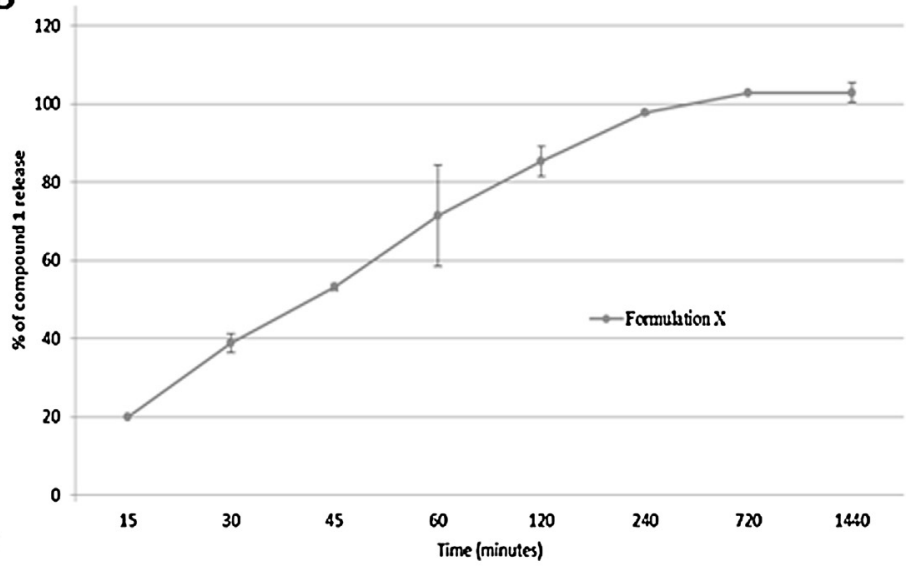

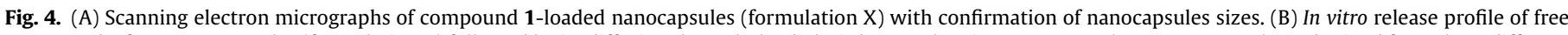

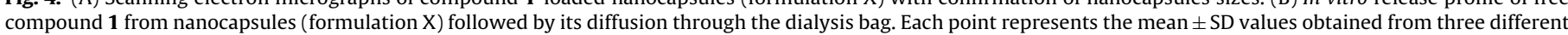
batches. 
been reported to be strongly dependent on their surface properties (Jong and Borm, 2008) and particularly on their charge (Mura et al., 2011), the lowest zeta potential values obtained for empty and loaded formulations $\mathrm{X}(-14.37 \pm 0.49$ and $-15.20 \pm 0.64 \mathrm{mV})$ could had significant influence in the lowest in vitro toxicity observed. Consequently, the amount and type of excipients present in the final formulation of nanoparticles may play a critical role in the future therapeutic application of this technology. The evaluation of the cytotoxicity of empty nanoparticles is thereby an important issue when developing new nanoparticle formulations and the correlation of the surface properties of polymeric nanoparticles with their cytotoxicity deserves further attention.

From the overall results on cell growth effects, it can be inferred that, the cytotoxic effect of formulation $\mathrm{X}$, nanoparticles with amounts of PLGA and PVA below 2.17 and $6.52 \mathrm{mg} / \mathrm{ml}$, may be only due to the effect of the incorporated compound (Fig. 2). At the time this study was being carried out, another study on solid dispersions of $\alpha$-mangostin (Fig. 1) in polyvinylpyrrolidone (PVP) revealed the enhancement of $\alpha$-mangostin solubility and intracellular delivery, although, no enhancement of $\alpha$-mangostin cytotoxic effect was observed with this formulation (Aisha et al., 2012). Herein, this study furnished a formulation of the hit compound with a three-fold improvement in the $\mathrm{GI}_{50}$ values in MCF-7 cell line. Additionally, an efficient internalization of 6-coumarin nanocapsules was achieved. Entrapment of a fluorescent probe within the nanocapsules enabled us to confirm that they were internalized as intact nanocapsules, releasing the fluorescent compound only in the cell cytoplasm.

Drug release studies from the nanoparticles are generally performed to understand the rate and mechanism of drug release rather than as a routine quality control method as used in the case of conventional dosage forms (Panyam and Labhasetwar, 2004). In vitro studies indicated that the presence of the polymer did not affect the release of compound $\mathbf{1}$, being the partition between the oily core and the external aqueous medium the main factor governing the process, as already reported for other drugs (Mora-Huertas et al., 2010; Santos-Magalhães et al., 2000; Teixeira et al., 2005a).

\section{Conclusions}

In the present integrative work, several techniques have been employed for the development of polymeric nanoparticle formulations of a poorly water-soluble dihydropyranoxanthone, inhibitor of p53-MDM2 interaction (compound 1). This allowed to enhance compound $\mathbf{1}$ concentration in aqueous solutions by a minimum of two-fold in nanospheres to 13-fold in nanocapsules. From the five selected formulations, only one prepared by ESE with PVA as surfactant showed no significant toxicity in the cell line studies. The developed formulation with favorable technological parameters led to three-fold improvement in the $\mathrm{GI}_{50}$ values of compound $\mathbf{1}$ and could be a valuable strategy as pharmaceutical carriers of xanthones.

\section{Acknowledgements}

To FCT - Fundação para a Ciência e a Tecnologia PEst-OE/SAU/UI4040/2011 and PTDC/SAU-FAR/110848/2009 under the project CEQUIMED, and REEQ/1062/CTM/2005 and REDE/1512/RME/2005 - CEMUP; FEDER through the COMPETE program under the projects FCOMP-01-0124-FEDER-011057 and FCOMP-01-0124-FEDER-015752; and to U. Porto/Santander Totta for financial support. To Sara Cravo for technical support. A.M. Paiva (PTDC/SAU-FCT/100930/2008; Liga Portuguesa Contra o Cancro/Pfizer) and R. T. Lima (SFRH/BPD/68787/2010) are thankful to FCT and Liga Portuguesa Contra o Cancro/Pfizer for their grants.
IPATIMUP is an Associate Laboratory of the Portuguese Ministry of Science, Technology and Higher Education and is partially supported by FCT.

\section{References}

Aisha, A.F.A., Ismail, Z., Abu-salah, K.M., Majid, A.M.S.A., 2012. Solid dispersions of $\alpha$-mangostin improve its aqueous solubility through self-assembly of nanomicelles. J. Pharm. Sci. 101, 815-825.

Azevedo, C., Afonso, C., Pinto, M., 2012. Routes to xanthones: an update on the synthetic approaches. Curr. Org. Chem. 16, 2818-2867.

Bernardi, A., Zilberstein, A., Jäger, E., Campos, M.M., Morrone, F.B., Calixto, J.B., Pohlmann, A.R., Guterres, S.S., Battastini, A.M.O., 2009. Effects of indomethacinloaded nanocapsules in experimental models of inflammation in rats. Br. J. Pharmacol. 158, 1104-1111.

Chen, H., Khemtong, C., Yang, X., Chang, X., Gao, J., 2011. Nanonization strategies for poorly water-soluble drugs. Drug Discov. Today 16, 354-360.

Chitchumroonchokchai, C., Thomas-Ahner, J.M., Li, J., Riedl, K.M., Nontakham, J., Suksumrarn, S., Clinton, S.K., Kinghorn, A.D., Failla, M.L., 2013. Anti-tumorigenicity of dietary $\alpha$-mangostin in an HT-29 colon cell xenograft model and the tissue distribution of xanthones and their phase II metabolites. Mol. Nutr. Food Res. 57, 203-211.

DeMerlis, C.C., Schoneker, D.R., 2003. Review of the oral toxicity of polyvinyl alcohol (PVA). Food Chem. Toxicol. 41, 319-326.

Fessi, H., Puisieux, F., Devissaguet, J.P., Ammoury, N., Benita, S., 1989. Nanocapsule formation by interfacial polymer deposition following solvent displacement. Int. J. Pharm. 55, R1-R4.

Jong, W.H.D., Borm, P.J., 2008. Drug delivery and nanoparticles: applications and hazards. Int. J. Nanomed. 3, 133-149.

Leão, M., Gomes, S., Pedraza-Chaverri, J., Machado, N., Sousa, E., Pinto, M., Inga, A., Pereira, C., Saraiva, L., 2013a. $\alpha$-Mangostin and gambogic acid as potential inhibitors of p53-MDM2 interaction revealed by a yeast approach. J. Nat. Prod., http://dx.doi.org/10.1021/np400049j.

Leão, M., Pereira, C., Bisio, A., Ciribilli, Y., Paiva, A.M., Machado, N., Palmeira, A., Fernandes, M.X., Sousa, E., Pinto, M., Inga, A., Saraiva, L., 2013b. Discovery of a new small-molecule inhibitor of p53-MDM2 interaction using a yeast-based approach. Biochem. Pharmacol. 85, 1234-1245.

Levy, M.Y., Benita, S., 1990. Drug release from submicronized O/W emulsion: a new in vitro kinetic evaluation model. Int. J. Pharm. 66, 29-37.

Li, L., Brunner, I., Han, A.-R., Hamburger, M., Kinghorn, A.D., Frye, R., Butterweck, V., 2011. Pharmacokinetics of $\alpha$-mangostin in rats after intravenous and oral application. Mol. Nutr. Food Res. 55, S67-S74.

Mohanraj, V.J., Chen, Y., 2006. Nanoparticles - a review. Trop. J. Pharm. Res. 5, 561-573.

Mora-Huertas, C.E., Fessi, H., Elaissari, A., 2010. Polymer-based nanocapsules for drug delivery. Int. J. Pharm. 385, 113-142.

Mura, S., Hillaireau, H., Nicolas, J., Le Droumaguet, B., Gueutin, C., Zanna, S., Tsapis, N., Fattal, E., 2011. Influence of surface charge on the potential toxicity of PLGA nanoparticles towards Calu-3 cells. Int. J. Nanomed. 6, 2591-2605.

Olivier, J.-C., 2005. Drug transport to brain with targeted nanoparticles. NeuroRx 2, 108-119.

Paiva, A.M., Sousa, M.E., Camões, A., Nascimento, M.S.J., Pinto, M.M.M., 2012. Prenylated xanthones: antiproliferative effects and enhancement of the growth inhibitory action of 4-hydroxytamoxifen in estrogen receptor-positive breast cancer cell line. Med. Chem. Res. 21, 552-558.

Palmeira, A., Paiva, A., Sousa, E., Seca, H., Almeida, G.M., Lima, R.T., Fernandes, M.X., Pinto, M., Vasconcelos, M.H., 2010. Insights into the in vitro antitumor mechanism of action of a new pyranoxanthone. Chem. Biol. Drug Des. 76, 43-58.

Panyam, J., Labhasetwar, V., 2004. Biodegradable nanoparticles for drug and gene delivery to cells and tissue. Adv. Drug Deliv. Rev. 55, 329-347.

Pinto, M., Castanheiro, R., 2009. Natural prenylated Xanthones: chemistry and biological activities. In: Narosa Publisihing House PVT, Ltd (Ed.), Natural Products: Chemistry, Biochemistry and Pharmacology. Narosa Publisihing House PVT, Ltd, West Bengal, pp. 521-675.

Pinto, M.M.M., Sousa, M.E., Nascimento, M.S.J., 2005. Xanthone derivatives: new insights in biological activities. Curr. Med. Chem. 12, 2517-2538.

Queiroz, M.J., Calhelha, R.C., Vale-Silva, L.A., Pinto, E., Lima, R.T., Vasconcelos, M.H., 2010. Efficient synthesis of 6-(hetero)arylthieno[3,2-b]pyridines by SuzukiMiyaura coupling. Evaluation of growth inhibition on human tumor cell lines, SARs and effects on the cell cycle. Eur. J. Med. Chem. 45, 5628-5634.

Quintanar-Guerrero, D., Allémann, E., Doelker, E., Fessi, H., 1998. Preparation and characterization of nanocapsules from preformed polymers by a new process based on emulsification-diffusion technique. Pharm. Res. 15, 1056-1062.

Quintanar-Guerrero, D., Fessi, H., Allémann, E., Doelker, E., 1996. Influence of stabilizing agents and preparative variables on the formation of poly(-lactic acid) nanoparticles by an emulsification-diffusion technique. Int. J. Pharm. 143, 133-141.

Reis, C.P., Neufeld, R.J., Ribeiro, A.J., Veiga, F., 2006. Nanoencapsulation I. Methods for preparation of drug-loaded polymeric nanoparticles. Nanomedicine: NBM 2 , $8-21$.

Rowe, R.C., Sheskey, P.J., Quinn, M.E., 2009. Handbook of Pharmaceutical Excipients. Pharmaceutical Press and American Pharmacists Association, Washington, USA. 
Santos-Magalhães, N.S., Pontes, A., Pereira, V.M.W., Caetano, M.N.P., 2000. Colloidal carriers for benzathine penicillin G: nanoemulsions and nanocapsules. Int. J. Pharm. 208, 71-80.

Semete, B., Booysen, L., Lemmer, Y., Kalombo, L., Katata, L., Verschoor, J., Swai, H.S. 2010. In vivo evaluation of the biodistribution and safety of PLGA nanoparticles as drug delivery systems. Nanomedicine: NBM 6, 662-671.

Sousa, E., Palmeira, A., Cordeiro, A., Sarmento, B., Ferreira, D., Lima, R., Helena Vasconcelos, M., Pinto, M., 2012. Bioactive xanthones with effect on P-glycoprotein and prediction of intestinal absorption. Med. Chem. Res., 1-9.

Teixeira, M., Alonso, M.J., Pinto, M.M.M., Barbosa, C.M., 2005a. Development and characterization of PLGA nanospheres and nanocapsules containing xanthone and 3-methoxyxanthone. Eur. J. Pharm. Biopharm. 59, 491-500.
Teixeira, M., Cerqueira, F., Barbosa, C.M., Nascimento, M., Pinto, M., 2005b. Improvement of the inhibitory effect of xanthones on NO production by encapsulation in PLGA nanocapsules. J. Drug Target. 13, 129-135.

Vaz, J.A., Heleno, S.A., Martins, A., Almeida, G.M., Vasconcelos, M.H., Ferreira, I.C. 2010. Wild mushrooms Clitocybe alexandri and Lepista inversa: in vitro antioxidant activity and growth inhibition of human tumour cell lines. Food Chem. Toxicol. 48, 2881-2884.

Vichai, V., Kirtikara, K., 2006. Sulforhodamine B colorimetric assay for cytotoxicity screening. Nat. Protoc. 1, 1112-1116.

Zili, Z., Sfar, S., Fessi, H., 2005. Preparation and characterization of poly[epsilon]-caprolactone nanoparticles containing griseofulvin. Int. J. Pharm. 294, 261-267. 